\title{
Effects of feeding rumen-protected linseed fat to postpartum dairy cows on plasma n-3 polyunsaturated fatty acid concentrations and metabolic and reproductive parameters
}

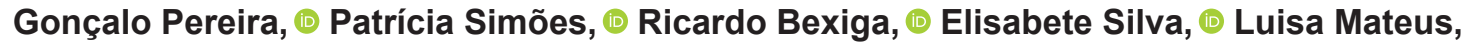 \\ Tatiane Fernandes, (D) Susana P. Alves, (D) Rui J. B. Bessa, (D) and Luis Lopes-da-Costa* (1) \\ CIISA-Centro de Investigação Interdisciplinar em Sanidade Animal, Faculdade de Medicina Veterinária, Universidade de Lisboa, \\ Avenida da Universidade Técnica, 1300-477 Lisboa, Portugal
}

\begin{abstract}
High-yielding dairy cows experience a negative energy balance and inflammatory status during the transition period. Fat supplementation increases diet energy density, and plasma n-3 polyunsaturated fatty acids (PUFA) have been proposed to improve immune function. This study tested the hypothesis that dietary supplementation with a rumen-protected and n-3 PUFA-enriched fat could ameliorate both the energetic deficit and immune status of postpartum high-yielding dairy cows, improving overall health and reproductive efficiency. At $11 \mathrm{~d}$ in milk (DIM), cows were randomly allocated to groups (1) n-3 PUFA ( $\mathrm{n}=29)$, supplemented with encapsulated linseed oil supplying additional up to $64 \mathrm{~g} / \mathrm{d}$ (mean $25 \pm 4 \mathrm{~g} / \mathrm{d}$ ) of $\alpha$-linolenic acid (ALA), or (2) control $(\mathrm{n}=31)$, supplemented with hydrogenated palm oil without ALA content. Fat supplements of the n-3 PUFA and control groups were available through an automated, off-parlor feeding system, and intake depended on the cow's feeding behavior. Plasma ALA concentrations were higher in n-3 PUFA than control cows, following a linear relation with supplement ingestion, resulting in a lower n- $6 / \mathrm{n}-3$ ratio in plasma. Metabolic parameters (body condition score and glucose and $\beta$-hydroxybutyric acid blood concentrations) were unaffected, but milk yield improved with increased intake of fat supplements. Plasma total adiponectin concentrations were negatively correlated with ingestion of n-3 PUFA-enriched fat supplement, following a linear relation with intake. Conception rate to first AI increased with higher intake of both fats, but a decrease of calving-to-conception interval occurred only in n-3 PUFA cows. Postpartum ovarian activity and endometrial inflammatory status at 45 DIM were unaffected. In conclusion, this study evinced a posi-
\end{abstract}

Received April 28, 2021.

Accepted August 28, 2021.

*Corresponding author: lcosta@fmv.ulisboa.pt tive linear relation between rumen-protected linseed fat intake and plasma n-3 PUFA concentrations, which modulated adiponectin expression and improved reproductive parameters.

Key words: n-3 PUFA, adiponectin, linseed, dairy cow

\section{INTRODUCTION}

The high-yielding dairy cow transition period is characterized by a state of negative energy balance, which adversely affects cow health, fertility, and milk yield (Raboisson et al., 2014; Abdelli et al., 2017; Sheldon et al., 2019). Fat supplementation has become a common strategy to increase the energy density of diets and minimize the effects of negative energy balance (Palmquist and Jenkins, 2017; Bionaz et al., 2020). However, this may reduce DMI, disturb rumen function, and originate fatty acid (FA) isomers that depress milk fat (Chamberlain and DePeters, 2017; de Souza and Lock, 2019; Manriquez et al., 2019). Because FA, namely PUFA, have essential physiologic roles, the beneficial effects of fat supplementation may rely more on FA type than on increased energy intake (Herrera-Camacho et al., 2011). In this context, the PUFA from n-3 ( $\alpha$-linolenic acid, ALA; eicosapentaenoic acid, EPA; docosapentaenoic acid, DPA; and docosahexaenoic acid, DHA) and n-6 (linoleic acid, LA; and arachidonic acid) families receive special attention due to their roles in reproductive and immune function (Moallem, 2018; Moallem et al., 2020). Increased intake of n-6 PUFA increases the proportion of LA and arachidonic acid in cell membranes, favoring eicosanoid synthesis toward a proinflammatory state (Wolf et al., 2019). In contrast, increased intake of n-3 PUFA increases the proportion of EPA and DHA in cell membranes, which favors eicosanoid synthesis toward an anti-inflammatory state (Greco et al., 2015; Wolf et al., 2019).

Transition dairy cows are good candidates for the modulation of inflammation through nutrition, because they experience a physiologic inflammatory state dur- 
ing the puerperal period (Bradford et al., 2015). A proinflammatory state characterizes initial uterine involution directed to elimination of endometrial pathogens by immune cells (LeBlanc, 2012). Then, it switches to a pro-resolving state, where restoration of endometrial homeostasis occurs. Failure to regulate this shift results in persistent chronic endometrial inflammation (subclinical or cytological endometritis, CYTO; Pascottini and LeBlanc, 2020). Recently a link was unveiled between the metabolic and immune functions at the endometrial level through adipokine signaling (adiponectin and chemerin; Pereira et al., 2020). In neonatal calves, transfer of n-3 PUFA into the plasma may also take place via placenta during late gestation or via colostrum (Uken et al., 2021a), and n-3 PUFA supplementation of colostrum increases plasma n-3 PUFA content, with beneficial effects on the inflammatory response (Opgenorth et al., 2020) and metabolic and endocrine development (Uken et al., 2021b).

This study evaluated the effects of feeding a rumenprotected linseed fat supplement to postpartum highyielding dairy cows on metabolic and reproductive parameters. The hypothesis to be tested was that feeding a rumen-protected linseed fat rich in ALA would increase blood n-3 PUFA concentrations, resulting in enhanced endometrial homeostasis at the end of the voluntary waiting period and increased fertility.

\section{MATERIALS AND METHODS}

\section{Ethics Statement}

The project was approved by the Institutional Animal Care and Use Committee (CEIE: Comissão de Ética para a Investigação e Ensino, Lisboa, Portugal; reference no. 36/2019). All clinical procedures were conducted in compliance with the European Union legislation to use animals for experimental purposes (Directive 2010/63/UE).

\section{Animals and Experimental Design}

The field study took place in a commercial dairy herd milking 550 Holstein-Friesian cows 3 times per day, with an average milk yield of $13,800 \mathrm{~L} / \mathrm{cow}$ over $305 \mathrm{~d}$ of lactation. Once calved, blood was sampled to assess cows' total calcium (at 0 DIM) and nonesterified fatty acids (NEFA) (at 0, 7, 14, and 21 DIM). Cows experiencing dystocia, retained fetal membranes, puerperal metritis or mastitis, clinical hypocalcemia, clinical ketosis, or severe lameness until 11 DIM were removed from the study. At $11 \pm 0.3$ DIM, cows $(\mathrm{n}=$
60 ) were stratified by parity and randomly assigned to 1 of 2 groups, receiving different fat supplements during 9 wk: (1) the n-3 PUFA group ( $\mathrm{n}=29 ; 14$ primiparous and 15 multiparous) received a rumen-protected n-3 fat (linseed oil encapsulated with a proprietary coating technology by SIPENA, Saint Malo, France) mixed with excipient (Eurocereal); and (2) the control group ( $\mathrm{n}=31 ; 16$ primiparous and 15 multiparous) received an isoenergetic supplement with saturated FA (hydrogenated palm oil mixed with the same excipient). The number of enrolled cows was chosen to allow detection of a $25 \%$ increase in plasma ALA concentrations $(\alpha=$ 0.05 ), and operators were blinded to cow group allocation. Milk samples were collected weekly until $11 \mathrm{wk}$ postpartum (WPP) and analyzed for milk composition. Body condition score was evaluated and blood samples collected once a week, from 11 DIM until 11 WPP (Figure 1) for analysis of FA and glucose, BHB, and progesterone $(\mathbf{P} 4)$ concentrations. At $23 \pm 0.5$ and $44 \pm 0.6$ DIM, vaginal discharge scoring, ultrasound genital tract evaluation, and endometrial cytology were performed, and blood samples were addressed for total adiponectin concentrations (Figure 1).

\section{Diet, Fat Supplements, and DMI}

Cows were kept as a single group and offered a TMR diet, with an estimated DMI of $25.0 \mathrm{~kg} /$ cow per day. Ingredients of TMR as well as TMR nutrient concentrations were analyzed by near-infrared spectroscopy (Table 1). Individual supplementation was provided through an automated, off-parlor feeding system (DairyFeed C-8000, GEA Farm Technologies), allowing $1.25 \mathrm{~kg} / \mathrm{d}$ of supplement in 4 feeding windows, and the daily intake was recorded by the cow-collar electronic system. The basal TMR diet supplied $38 \mathrm{~g} / \mathrm{d}$ per cow of ALA, and n-3 PUFA cows received up to $64 \mathrm{~g} / \mathrm{d}$ (mean $25 \pm 4 \mathrm{~g} / \mathrm{d}$ ) of additional ALA, whereas control cows received no additional ALA.

\section{Blood and Milk Sampling}

Blood samples were aseptically collected by venipuncture of the coccygeal vein into $10-\mathrm{mL}$ dry tubes and 10-mL tubes containing K3 EDTA (13060, Vacutest Kima). Tubes were centrifuged (2,000 g for $15 \mathrm{~min})$ within 30 min of collection, and serum and plasma were aliquoted into $1.5-\mathrm{mL}$ tubes and stored at $-80^{\circ} \mathrm{C}$ until analysis. Composite milk samples were automatically collected during the afternoon milking, dispensed into a 50 -mL tube with bronopol, and stored at $4^{\circ} \mathrm{C}$ until milk composition analysis. 
Table 1. Ingredient composition and nutrient concentrations of the TMR and fat supplements delivered to cows enrolled in the supplementation trial

\begin{tabular}{|c|c|c|c|}
\hline \multirow[b]{2}{*}{ Item } & \multirow[b]{2}{*}{ TMR } & \multicolumn{2}{|c|}{ Fat supplement } \\
\hline & & Control & n-3 PUFA \\
\hline \multicolumn{4}{|l|}{ Ingredient ( $\%$ of DM) } \\
\hline Corn silage & 29.1 & - & - \\
\hline Ryegrass hay & 12.6 & - & - \\
\hline Barley grain & 27.8 & - & - \\
\hline Brewers yeast & 2.1 & - & - \\
\hline Soybean meal & 13.9 & - & - \\
\hline Beet molasses & 3.0 & - & - \\
\hline Rice bran & 3.5 & - & - \\
\hline Palm kernel meal & 3.9 & - & - \\
\hline Palmitic acid $98 \%$ & 1.1 & - & - \\
\hline Mineral and vitamin premix & 2.9 & - & - \\
\hline \multicolumn{4}{|c|}{ Nutrient concentration $^{1}(\%$ of DM) } \\
\hline$\% \mathrm{DM}$ & 51.6 & 90.7 & 91 \\
\hline $\mathrm{CP}$ & 16.9 & 14.4 & 13.5 \\
\hline Crude fat & 4.3 & 15.6 & 14.6 \\
\hline Starch & 26.4 & 18.4 & 20.6 \\
\hline NDF & 32.5 & 21.4 & 20 \\
\hline $\mathrm{ADF}$ & 18.9 & - & - \\
\hline ADL & 2.9 & - & - \\
\hline Ash & 8.6 & 10.2 & 11.4 \\
\hline $\mathrm{NE}_{\mathrm{L}}(\mathrm{Mcal} / \mathrm{kg}$ of $\mathrm{DM})$ & 1.702 & - & - \\
\hline \multicolumn{4}{|c|}{ Fatty acids ( $\mathrm{g} / 100 \mathrm{~g}$ of total fatty acids) } \\
\hline 14:0 & 0.91 & 1.5 & 0.1 \\
\hline 16:0 & 43.4 & 46.5 & 5.3 \\
\hline $18: 0$ & 3.63 & 47.5 & 30.8 \\
\hline $18: 1$ cis-9 & 17.8 & 4.5 & 11.8 \\
\hline $18: 1$ cis- 11 & 1.38 & - & 0.4 \\
\hline $18: 2 n-6$ & 28.5 & - & 10.5 \\
\hline $18: 3 n-3$ & 3.32 & - & 40 \\
\hline $20: 0$ & 0.38 & - & 0.6 \\
\hline Others & 0.59 & - & 0.5 \\
\hline
\end{tabular}

${ }^{1}$ Analyzed by near-infrared spectroscopy.

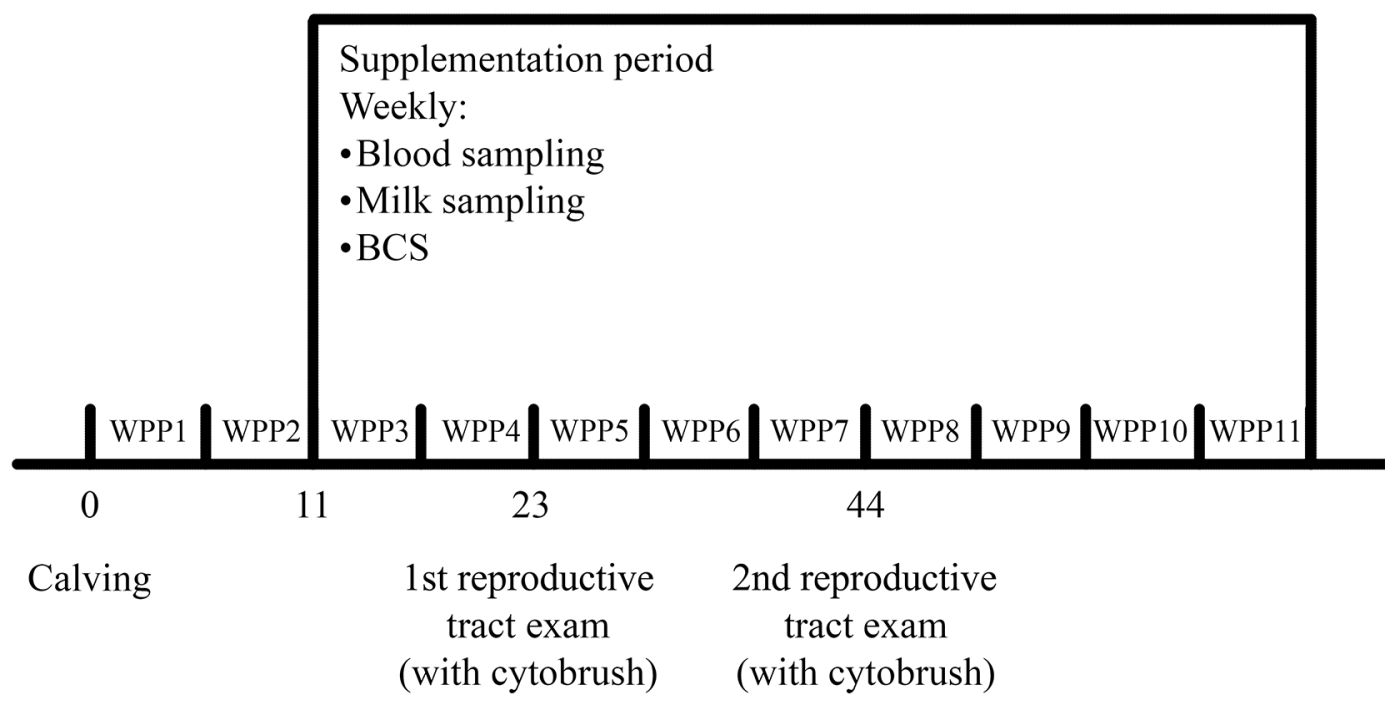

Figure 1. Experimental design. WPP = week postpartum. 


\section{Plasma FA Profile}

Fatty acid methyl esters from freeze-dried plasma samples were prepared by transesterification with sodium methoxide in methanol $\left(0.5 \mathrm{M}\right.$, at $50^{\circ} \mathrm{C}$ for 30 $\min )$, followed by $\mathrm{HCl}$ in methanol $\left(1.25 \mathrm{M}\right.$, at $80^{\circ} \mathrm{C}$ for $20 \mathrm{~min})$, with the addition of methyl nonadecanoate (1 $\mathrm{mL}$ of a $1 \mathrm{mg} / \mathrm{mL}$ solution) as internal standard (Alves et al., 2017). Fatty acid methyl esters were analyzed by gas chromatography with flame ionization detection using a Shimadzu GC 2010-Plus equipped with an SP2560 capillary column $(100 \mathrm{~m} \times 0.25 \mathrm{~mm}, 0.20-\mu \mathrm{m}$ film thickness, Supelco Inc.). The chromatographic conditions were as follows: injector and detector temperatures were set at 220 and $250^{\circ} \mathrm{C}$, respectively; helium was used as the carrier gas at $1 \mathrm{~mL} / \mathrm{min}$ constant flow; the initial oven temperature of $50^{\circ} \mathrm{C}$ was held for $1 \mathrm{~min}$, increased at $50^{\circ} \mathrm{C} / \mathrm{min}$ to $175^{\circ} \mathrm{C}$ and held for $35 \mathrm{~min}$, increased at $2^{\circ} \mathrm{C} / \mathrm{min}$ to $220^{\circ} \mathrm{C}$ and held for $30 \mathrm{~min}$. Identification of FAME was achieved by comparison of the FAME retention times with those of commercial standards (FAME mix 37 components from Supelco Inc.) and by mass spectrometry using a GC-MS Shimadzu 2010-Plus. Integration of peaks was performed using GCsolution Version 2.41.00 (Shimadzu, 2000-2011). Theoretical relative flame ionization detection response correction factors for FAME were used to correct peak areas, according to Ackman (2002).

\section{BCS and Energy Balance Indicators}

Cows were scored for BCS using a 1-to-5 scale with 0.25 increments (Ferguson et al., 1994). Within $30 \mathrm{~min}$ of blood collection, glucose and BHB concentrations were assessed with a handheld device (Precision Xtra, Abbott Diabetes Care) in blood with EDTA added. Serum NEFA concentrations were determined by a colorimetric method (kit no. FA 115, Randox) using Randox RX Daytona equipment, as described by Pereira et al. (2020). The analytical sensitivity of the assay was 0.072 $\mathrm{mmol} / \mathrm{L}$, and the interassay coefficient of variation was $<5 \%$. Serum total calcium concentrations at calving were determined by a colorimetric method (kit no. CA 3871, Randox), with a $0.09 \mathrm{mmol} / \mathrm{L}$ analytical sensitivity.

\section{Adiponectin Assay}

Plasma total adiponectin concentrations were assessed as previously described (Mellouk et al., 2017; 2019; Pereira et al., 2020) with an ELISA commercial kit (E11A0125, BlueGene). The intra- and interassay coefficients of variation were $4.2 \%$ and $15 \%$, respectively.

\section{Milk Yield and Composition}

Milk yield was retrieved from the milking parlor recording system (3 times daily). Milk composition, including fat mass percentage $(\% \mathrm{~m} / \mathrm{m})$ and $\mathrm{CP}$ mass percentage $(\% \mathrm{~m} / \mathrm{m})$, were analyzed by mid-infrared spectroscopy (MilkoScan 7, Foss), and SCC (cells/mL $\times 1,000$ ) was analyzed by flow cytometry (Fossomatic, Foss) within $24 \mathrm{~h}$ of collection. The fat- (4\%) and protein- $(3.3 \%)$ corrected milk (FPCM) was calculated according to Kok et al. (2017) as follows: FPCM = milk $(\mathrm{kg}) \times(0.337+0.116 \times$ fat $\%+0.06 \times \mathrm{CP} \%)$.

\section{Genital Tract Evaluation and Endometrial Cytology}

Vaginal fornix discharge was collected through a Metricheck device, and the score was evaluated as described by Williams et al. (2005). Then, the genital tract was assessed through transrectal palpation and ultrasonography, and an endometrial swab was performed to evaluate endometrial cytology, as described by Pereira et al. (2020). Briefly, a cervical brush (Bastos Viegas SA) was aseptically adapted to the inner stylet of an AI gun (IMV Technologies) and gently rolled against the endometrium in the uterine body. Slides were stained with a modified Wright-Giemsa stain (Diff-Quick, MAIM SL), and the percentage of PMN was assessed from 400 total cells. The PMN cut-offs for identification of CYTO were set at $\geq 18 \%$ (Kasimanickam et al., 2004) and $\geq 5 \%$ (Gilbert et al., 2005) at 23 and 44 DIM, respectively.

\section{Progesterone Assay}

Plasma progesterone concentrations were assayed by a chemiluminescent immunoassay, using an Immulite 1000 analyzer (Siemens Healthcare Diagnostics) and a commercial kit (Immulite 1000 Progesterone Kit, Siemens Healthcare Diagnostics), as validated for bovine samples by Martin et al. (2007). The analytical sensitivity of the assay was $0.2 \mathrm{ng} / \mathrm{mL}$, and the interassay coefficient of variation was $<10 \%$. The onset of postpartum ovarian luteal activity was considered to occur at the first P4 measurement $>1 \mathrm{ng} / \mathrm{mL}$ (Colazo et al., 2008), and postpartum ovarian patterns were defined as described by Lamming and Darwash (1998).

\section{Reproductive Management}

Cows were inseminated at the first observed estrus after 45 DIM. Cows not exhibiting estrus by 75 DIM were enrolled in an OvSynch plus FTAI protocol. Pregnancy was detected by ultrasound at $39 \mathrm{~d}$ after AI. 


\section{Statistical Analysis}

Data were compiled using Excel 2013 (Microsoft Corp.) spreadsheets before being imported into SAS (version 9.4, SAS Institute Inc.) for data analysis. The continuous response variables with repeated measures (FPCM, milk fat and protein percentages, BCS, glucose, BHB, NEFA, FA, and adiponectin) were analyzed by fitting linear mixed models with PROC MIXED of SAS. Serum calcium at calving and total fat supplement ingestion were analyzed by fitting linear models with PROC GLM. Binary response variables (CYTO at 23 and 44 DIM, pregnancy status after first AI, and postpartum P4 pattern) were analyzed by fitting generalized linear mixed models with a logit link and a binomial distribution, using PROC GLIMMIX. As recommended by Lean et al. (2016), intervals from calving to onset of postpartum ovarian luteal activity and from calving to conception (CCI) were analyzed by multivariable survival analysis using Cox proportional hazard regression (PROC PHREG).

The repeated-measures models had the cow specified as subject and included parity (primiparous or multiparous), fat supplement (n-3 PUFA or control), conception at first AI (yes or no), pregnancy at 150 DIM (yes or no), and CYTO at 23 and 44 DIM (yes or no) as fixed effects, and the amount of fat supplement ingested weekly $(\mathrm{kg})$ and DIM as covariates. The fat supplement intake was required because animals from both treatments presented intake values that varied continuously from zero to the maximum allowed. Thus, the effect of fat supplementation was evaluated by the interaction term of supplement type $\times$ supplement ingested weekly. The model of serum calcium at calving included the fixed effects of parity, fat supplement, conception at first AI, and CYTO at 23 and 44 DIM. This model was generated to evaluate putative effects of calcemia in uterine health and fertility, as suboptimal serum calcium concentrations at calving can be detrimental to uterine health (Martinez et al., 2012) and fertility (Caixeta et al., 2017), and can alter FA metabolism (Chamberlin et al., 2013) of postpartum dairy cows. The conception at first AI and postpartum P4 pattern generalized linear mixed models, and the interval from calving to the onset of postpartum ovarian luteal activity and CCI survival analysis models, included the fixed effects of parity, fat supplement, CYTO at 23 and 44 DIM, total fat supplement ingested $(\mathrm{kg})$ as a covariate, and the supplement type $\times$ total supplement ingested interaction term. For the survival analysis, cows were right-censored if not diagnosed pregnant at 240 DIM or if removed from the herd.

As suggested by Heinze and Dunkler (2017), manual backward elimination with a $P$-value criterion of 0.157 , without a preceding univariable prefiltering, was performed to obtain the final models. The assumption of homoscedasticity was evaluated visually using the plots of studentized residuals against predicted values, and the assumption of normality of residuals was evaluated using the Q-Q plots. To satisfy these assumptions, milk SCC, plasma adiponectin, and blood BHB concentrations were natural log-transformed. For models with repeated measures, the covariance structure that resulted in the lowest Akaike information criteria was selected. In the final models, differences were considered significant when $P \leq 0.05$, whereas a tendency was defined as $0.05<P \leq 0.10$.

\section{RESULTS}

\section{Fat Supplement Intake and Plasma FA Profile}

Cows from the n-3 PUFA group had higher $(P=$ 0.004; Table 2) total fat supplement intake than the cows of the control group. Mean total supplement intake was $33.2 \pm 3.8 \mathrm{~kg}$ and $17.7 \pm 3.7 \mathrm{~kg}$ for the $\mathrm{n}-3$ PUFA and control groups, respectively. Plasma concentrations of total, n-3, and n-6 PUFA increased with DIM $(P \leq 0.001)$. Plasma total FA concentrations were higher $(P=0.041)$ in multiparous than in primiparous cows, and were also affected by fat supplement ingestion $(P=0.001)$, increasing $1.26 \pm 0.39 \mathrm{mg} / \mathrm{dL}$ per kilogram ingested. Plasma n-3 PUFA concentrations were higher in the n-3 PUFA group than in the control group, increasing $(P \leq 0.001$; Table 3$)$ by 0.142 $\pm 0.026 \mathrm{mg} / \mathrm{dL}$ per kilogram of $\mathrm{n}-3$ PUFA supplement ingested, whereas no increase $(P=0.292)$ was observed in the control group. Plasma n-6 PUFA concentrations were increased $(P=0.002)$ by $0.676 \pm 0.212 \mathrm{mg} / \mathrm{dL}$ per kilogram of supplement ingested, irrespective of fat source. The $\mathrm{n}-6 / \mathrm{n}-3$ ratio decreased with DIM $(P$ $=0.001$ ), also decreasing by $0.183 \pm 0.023$ units per kilogram of n-3 PUFA ingestion $(P \leq 0.001$; Figure 2 ). Plasma ALA concentrations increased by $0.124 \pm$ $0.021 \mathrm{mg} / \mathrm{dL}$ with $\mathrm{n}-3$ PUFA ingestion $(P \leq 0.001$; Figure 2) and DIM $(P \leq 0.001)$. Increased intake of control fat produced no effect on the n-6/n-3 ratio ( $P$ $=0.988)$ or ALA $(P=0.393)$ plasma concentrations. Similarly to total n-6 PUFA, plasma LA concentrations increased with DIM $(P \leq 0.001)$ and fat supplement ingestion $(P=0.002)$, with no difference between the 2 fat supplements (Figure 2). Plasma EPA and DPA concentrations also increased with DIM $(P \leq 0.001)$ and supplement ingested $(P=0.004$ and $P=0.033$ for EPA and DPA, respectively), whereas DHA concentrations were not affected by either DIM or supplement ingested. Average concentrations of plasma FA at the end of the supplementation period (11 WPP), solved 
Table 2. Final models with statistical significance of parity, DIM, treatment (group; trt), fat supplement ingestion (fat sup. intake), cytological endometritis (CYTO), and interval from conception to first AI

\begin{tabular}{|c|c|c|c|c|c|c|c|c|}
\hline \multirow[b]{2}{*}{ Dependent variable $^{1}$} & \multicolumn{8}{|c|}{$P$-value ${ }^{2}$} \\
\hline & Parity & DIM & Trt & $\begin{array}{l}\text { Fat } \\
\text { sup. } \\
\text { intake }\end{array}$ & $\begin{array}{c}\text { Trt } \times \text { Fat } \\
\text { sup. } \\
\text { intake }^{1}\end{array}$ & $\begin{array}{c}\text { CYTO } \\
\text { at } \\
23 \mathrm{DIM}\end{array}$ & $\begin{array}{c}\text { CYTO } \\
\text { at } \\
44 \mathrm{DIM}\end{array}$ & $\begin{array}{c}\text { Conception } \\
\text { to } \\
\text { first AI }\end{array}$ \\
\hline Total fat supplement ingested (kg) & - & - & 0.004 & - & - & - & - & - \\
\hline FPCM yield $(\mathrm{kg} / \mathrm{wk})$ & $<0.001$ & 0.042 & - & 0.042 & - & - & - & - \\
\hline Milk fat percentage (\%) & - & $<0.001$ & - & - & - & - & - & - \\
\hline $\mathrm{BCS}$ & - & $<0.001$ & - & - & - & - & - & - \\
\hline Blood glucose (mmol/L) & $<0.001$ & - & - & - & - & - & 0.024 & - \\
\hline Blood BHB $(\mathrm{mmol} / \mathrm{L})$ & - & - & - & - & - & - & - & - \\
\hline Plasma adiponectin $(\mu \mathrm{g} / \mathrm{mL})$ & - & 0.002 & - & 0.072 & $<0.001$ & - & 0.040 & - \\
\hline Serum calcium at calving $(\mathrm{mmol} / \mathrm{L})$ & $<0.001$ & - & - & - & - & - & - & - \\
\hline NEFA $(\mathrm{mmol} / \mathrm{L})$ & 0.048 & 0.088 & - & - & - & - & - & 0.098 \\
\hline Total FA (mg/dL) & 0.041 & $<0.001$ & - & 0.001 & - & - & - & - \\
\hline$\alpha$-Linolenic acid (mg/dL) & 0.020 & $<0.001$ & - & $<0.001$ & 0.005 & - & - & 0.054 \\
\hline $\mathrm{EPA}(\mathrm{mg} / \mathrm{dL})$ & - & $<0.001$ & - & 0.004 & - & - & - & - \\
\hline $\mathrm{DPA}(\mathrm{mg} / \mathrm{dL})$ & - & $<0.001$ & - & 0.033 & - & - & - & - \\
\hline DHA (mg/dL) & - & - & - & - & - & - & - & - \\
\hline
\end{tabular}

${ }^{1} \mathrm{FPCM}=$ fat- and protein-corrected milk; NEFA = nonesterified fatty acid; FA = fatty acid; EPA = eicosapentaenoic acid; DPA = docosapentaenoic acid; DHA = docosahexaenoic acid.

${ }^{2}$ Variables not included in the final models are represented by dashes $(-)$.

for $1 \mathrm{~kg} / \mathrm{d}$ ingestion of fat supplements, are supplied in Table 4.

\section{Milk Yield and Metabolic Variables}

Fat- $(4 \%)$ and protein- $(3.3 \%)$ corrected milk yield increased $(P=0.042)$ with DIM, and was lower $(P$ $\leq 0.001)$ in primiparous than multiparous cows (Supplemental Figure S1, https://data.mendeley.com/

Table 3. Effects of control and n-3 PUFA fat supplement ingestion on plasma concentrations of fatty acids (FA) in postpartum dairy cows

\begin{tabular}{lccc}
\hline $\begin{array}{l}\text { Plasma fatty acid } \\
(\mathrm{mg} / \mathrm{dL})\end{array}$ & Control & $\mathrm{n}$-3 PUFA & $\begin{array}{c}P \text {-value for } \\
\text { differences }\end{array}$ \\
\hline Linoleic acid & $0.565^{*}$ & $0.640^{*}$ & 0.8516 \\
$\alpha$-Linolenic acid & $0.024 \dagger$ & $0.124^{*}$ & 0.0052 \\
EPA & $0.008 \dagger$ & $0.011^{*}$ & 0.6037 \\
DPA & $0.006 \dagger$ & $0.009 \dagger$ & 0.7387 \\
DHA & $0.000 \dagger$ & $0.000 \dagger$ & 0.5866 \\
Total n-3 FA & $0.035 \dagger$ & $0.142^{*}$ & 0.0110 \\
Total n-6 FA & $0.657^{*}$ & $0.694^{*}$ & 0.9339 \\
n-6/n-3 FA ratio & $0.000 \dagger$ & $-0.183^{*}$ & $<0.0001$ \\
Total FA & $1.090^{*}$ & $1.377^{*}$ & 0.7250 \\
\hline
\end{tabular}

${ }^{1}$ Values are slopes for 1 unit change in ingestion, $\mathrm{kg} / \mathrm{wk} . \mathrm{EPA}=$ eicosapentaenoic acid. DPA $=$ docosapentaenoic acid. $\mathrm{DHA}=$ docosahexaenoic acid.

*Slope differs from zero $(P<0.10)$; $\dagger$ slope does not differ from zero $(P \geq 0.10)$. datasets/j2bfm4tf9x/1; Pereira, 2021). Both milk fat $(P \leq 0.001)$ and protein $(P=0.003)$ percentages decreased with DIM. Intake of both fat supplements (control and n-3 PUFA) increased FPCM yield by 1.95 $\mathrm{kg}$ per kilogram ingested $(P=0.042)$, whereas milk fat and protein percentages remained unaffected.

Serum total calcium concentrations at calving (2.21 $\pm 0.06 \mathrm{mmol} / \mathrm{L}$ vs. $1.96 \pm 0.05 \mathrm{mmol} / \mathrm{L}, P<0.001)$ and plasma glucose concentrations throughout the study were higher $(P \leq 0.001)$ in primiparous than multiparous cows. Plasma NEFA concentrations were lower $(P$ $=0.048)$ in primiparous than multiparous cows, and BCS decreased $(P<0.001)$ with DIM (Supplemental Figure S1, Pereira, 2021). Plasma total adiponectin concentrations were increased in cows with CYTO at 44 DIM $(P=0.040$; Figure 3). Plasma total adiponectin concentrations displayed a negative linear relation with intake of n-3 PUFA supplement $(P=0.001)$, being 0.93 times lower per kilogram of n-3 PUFA supplement ingested during the week of sampling (Figure 3).

\section{Reproductive Variables}

Final reproductive outcome models are presented in Table 5. Fat supplementation had no effect on postpartum P4 profiles, which were normal in 28 of $60(47 \%)$ 
cows, whereas the remaining 32 cows presented atypical profiles (delayed ovulation or persistent luteal phase). The interval from calving to onset of postpartum ovarian luteal activity was not affected by fat supplementation and averaged $34.5 \pm 1.5 \mathrm{~d}$. Diagnosis of CYTO at 23 DIM affected the interval from calving to onset of postpartum ovarian luteal activity (CYTO cows had an ovulation hazard ratio of 0.425 compared with healthy cows). The conception rate at first AI was $25 \%$ (15 of 60 cows) and increased with fat supplementation $(P$ $=0.015)$. The odds of pregnancy at first AI increased 1.037 times for each kilogram of fat supplement ingested, irrespective of fat supplement. Regarding the CCI, primiparous cows had a higher $(P=0.034)$ hazard ratio of conception (1.832; 95\% Wald confidence limits: 1.045-3.211) than multiparous cows. After adjusting for the effect of parity, the hazard ratio of conception for cows ingesting n-3 PUFA increased $(P=0.004)$ 1.009 (95\% Wald confidence limits: 0.996-1.022) times for each kilogram ingested, whereas cows ingesting increased amounts of control fat supplement tended $(P$ $=0.062)$ to exhibit a lower hazard ratio of conception (0.977; 95\% Wald confidence limits: 0.954-1.001).

\section{DISCUSSION}

This study evaluated the effects of feeding a rumenprotected n-3 PUFA-enriched fat supplement on metabolic and reproductive indicators of high-yielding dairy cows. Treatment increased n-3 PUFA plasma concentrations, modulated plasma adiponectin concentrations, and shortened the calving-to-conception interval.
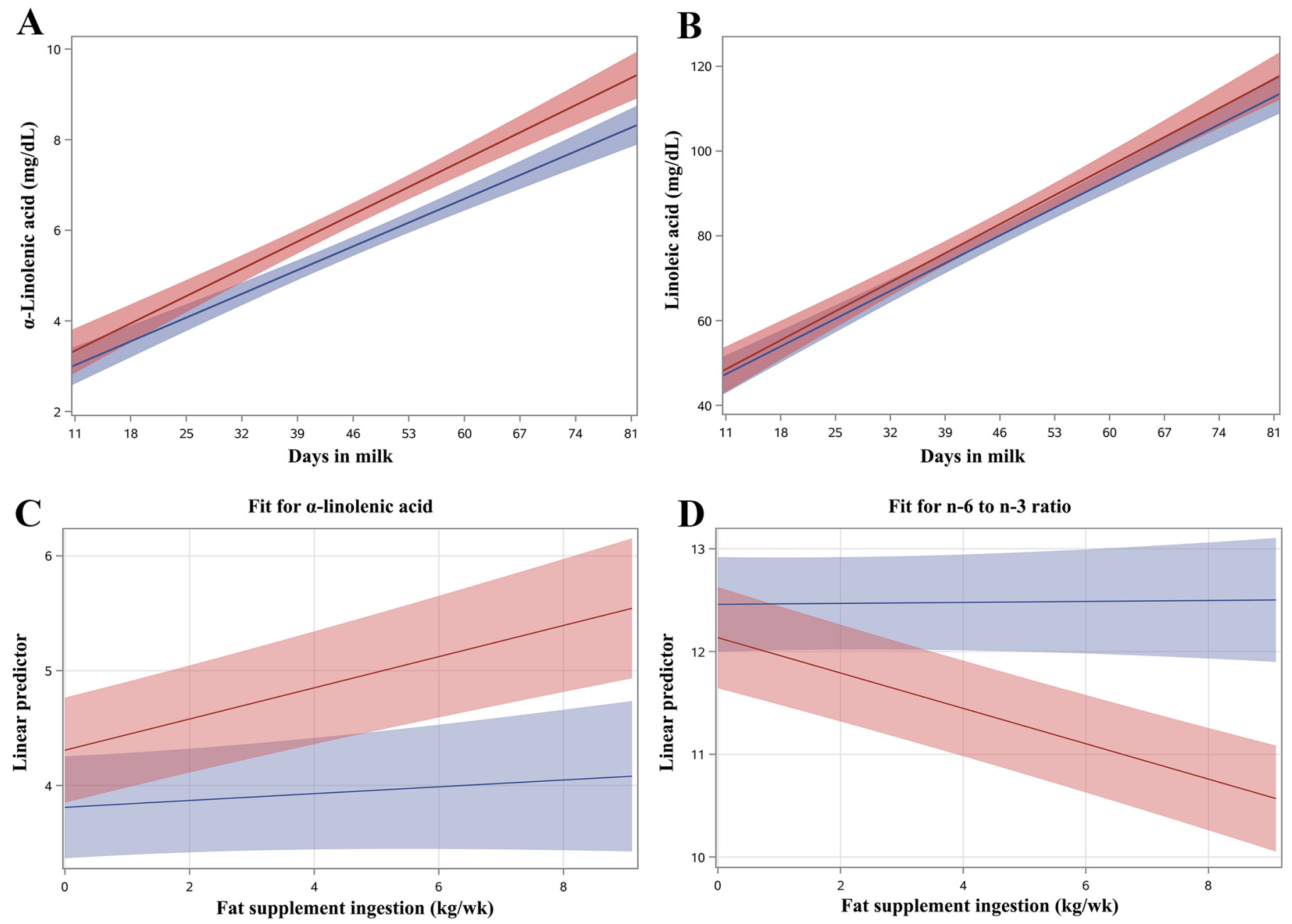

Figure 2. Plot of regression lines with respective $95 \%$ confidence limits of plasma $\alpha$-linolenic acid concentrations (A), linoleic acid concentrations (B), effect of varying rates of weekly fat supplement ingestion on plasma $\alpha$-linolenic acid concentrations (C), and plasma n-6 to n-3 ratio (D) in postpartum dairy cows ingesting control (blue) or n-3 PUFA (red) fat supplements. 
Table 4. Least squares means $( \pm \mathrm{SE})$ and $P$-values for the differences of plasma fatty acid (FA) concentrations of dairy cows at 11 wk postpartum ingesting $1 \mathrm{~kg} / \mathrm{d}$ of control or n-3 PUFA fat supplements

\begin{tabular}{|c|c|c|c|}
\hline $\mathrm{FA}^{1}(\mathrm{mg} / \mathrm{dL})$ & Control & n-3 PUFA & $\begin{array}{l}P \text {-value for } \\
\text { differences }\end{array}$ \\
\hline $12: 0$ & $0.22 \pm 0.02$ & $0.26 \pm 0.02$ & 0.1532 \\
\hline $14: 0$ & $1.69 \pm 0.07$ & $1.79 \pm 0.06$ & 0.2656 \\
\hline iso $15: 0$ & $0.49 \pm 0.02$ & $0.49 \pm 0.02$ & 0.9032 \\
\hline anteiso 15:0 & $1.08 \pm 0.06$ & $1.11 \pm 0.05$ & 0.6766 \\
\hline $14: 1$ cis-9 & $0.65 \pm 0.06$ & $0.51 \pm 0.06$ & 0.0813 \\
\hline $15: 0$ & $1.69 \pm 0.09$ & $1.59 \pm 0.08$ & 0.3825 \\
\hline 16:0 DMA & $0.37 \pm 0.11$ & $0.50 \pm 0.11$ & 0.3667 \\
\hline iso 16:0 & $0.32 \pm 0.02$ & $0.34 \pm 0.02$ & 0.4728 \\
\hline $16: 0$ & $28.82 \pm 1.06$ & $28.04 \pm 0.99$ & 0.5404 \\
\hline $16: 1$ trans & $0.44 \pm 0.03$ & $0.44 \pm 0.02$ & 0.9583 \\
\hline iso $17: 0$ & $1.07 \pm 0.04$ & $1.09 \pm 0.04$ & 0.6929 \\
\hline $16: 1 \mathrm{cis}-7$ & $1.16 \pm 0.13$ & $1.11 \pm 0.13$ & 0.7678 \\
\hline $16: 1$ cis -9 & $3.46 \pm 0.20$ & $3.51 \pm 0.20$ & 0.8021 \\
\hline anteiso $17: 0$ & $0.03 \pm 0.01$ & $0.02 \pm 0.01$ & 0.1643 \\
\hline $17: 0$ & $0.99 \pm 0.05$ & $1.00 \pm 0.04$ & 0.7964 \\
\hline 18:0 DMA & $0.45 \pm 0.03$ & $0.48 \pm 0.03$ & 0.4280 \\
\hline iso 18:0 & $0.03 \pm 0.01$ & $0.03 \pm 0.01$ & 0.4391 \\
\hline $17: 1$ cis-9 & $0.52 \pm 0.04$ & $0.58 \pm 0.04$ & 0.2208 \\
\hline $18: 0$ & $31.00 \pm 1.24$ & $32.31 \pm 1.14$ & 0.3504 \\
\hline 18:1 trans $-6 /$ trans $-7 /$ trans -8 & $0.20 \pm 0.02$ & $0.20 \pm 0.02$ & 0.8540 \\
\hline $18: 1$ trans -9 & $0.27 \pm 0.03$ & $0.29 \pm 0.02$ & 0.6546 \\
\hline 18:1 trans -10 & $0.55 \pm 0.09$ & $0.71 \pm 0.08$ & 0.1732 \\
\hline $18: 1$ trans -11 & $0.44 \pm 0.03$ & $0.45 \pm 0.03$ & 0.7324 \\
\hline 18:1 trans -12 & $0.33 \pm 0.03$ & $0.38 \pm 0.02$ & 0.1466 \\
\hline 18:1 trans- $13 /$ trans -14 & $1.31 \pm 0.06$ & $1.41 \pm 0.06$ & 0.1577 \\
\hline $18: 1$ cis -9 & $20.32 \pm 1.0$ & $19.07 \pm 0.9$ & 0.3139 \\
\hline 18:1 trans- 15 & $0.09 \pm 0.01$ & $0.08 \pm 0.01$ & 0.6228 \\
\hline $18: 1$ cis- 11 & $1.65 \pm 0.07$ & $1.62 \pm 0.07$ & 0.7689 \\
\hline $18: 1$ cis- 12 & $0.91 \pm 0.06$ & $0.98 \pm 0.05$ & 0.3604 \\
\hline $18: 1$ cis-13 & $0.07 \pm 0.01$ & $0.05 \pm 0.01$ & 0.2176 \\
\hline 18:1 trans $-16 /$ cis- 14 & $0.19 \pm 0.02$ & $0.16 \pm 0.01$ & 0.2719 \\
\hline 18:1 cis- 15 & $0.022 \pm 0.004$ & $0.017 \pm 0.003$ & 0.2884 \\
\hline 18:2 trans,trans & $0.08 \pm 0.01$ & $0.08 \pm 0.01$ & 0.6738 \\
\hline 18:2 trans,cis/cis,trans & $0.49 \pm 0.04$ & $0.53 \pm 0.03$ & 0.2761 \\
\hline $18: 1$ cis -16 & $0.16 \pm 0.02$ & $0.14 \pm 0.02$ & 0.5605 \\
\hline $18: 2$ trans -9, cis -12 & $0.14 \pm 0.02$ & $0.13 \pm 0.01$ & 0.6314 \\
\hline $18: 2$ trans- 11, cis- $15 /$ trans- 10, cis- 15 & $0.09 \pm 0.02$ & $0.08 \pm 0.02$ & 0.6814 \\
\hline $18: 2 \mathrm{n}-6$ & $107.46 \pm 4.24$ & $109.31 \pm 4.02$ & 0.6781 \\
\hline 20:0 & $0.07 \pm 0.01$ & $0.06 \pm 0.01$ & 0.7779 \\
\hline $18: 3 n-6$ & $2.22 \pm 0.12$ & $2.20 \pm 0.11$ & 0.8846 \\
\hline $20: 1$ cis-11 & $0.027 \pm 0.007$ & $0.022 \pm 0.005$ & 0.4471 \\
\hline $18: 3 n-3(\mathrm{ALA})$ & $8.06 \pm 0.37$ & $8.97 \pm 0.35$ & 0.0100 \\
\hline cis-9,trans-11 CLA & $0.05 \pm 0.01$ & $0.06 \pm 0.01$ & 0.2271 \\
\hline trans,trans CLA & $0.24 \pm 0.02$ & $0.28 \pm 0.02$ & 0.0510 \\
\hline $20: 2 n-6$ & $0.036 \pm 0.008$ & $0.031 \pm 0.007$ & 0.5267 \\
\hline 18:3 cis- 9 ,trans -11, cis- $15 / 20: 3 n-9$ & $0.23 \pm 0.02$ & $0.24 \pm 0.02$ & 0.5829 \\
\hline $22: 0$ & $0.041 \pm 0.009$ & $0.034 \pm 0.006$ & 0.5313 \\
\hline $20: 3 n-6$ & $5.23 \pm 0.26$ & $5.40 \pm 0.25$ & 0.5405 \\
\hline $20: 3 n-3$ & $0.011 \pm 0.006$ & $0.021 \pm 0.004$ & 0.2004 \\
\hline $20: 4 n-6$ & $4.90 \pm 0.28$ & $4.63 \pm 0.28$ & 0.4319 \\
\hline 20:5n-3 (EPA) & $1.00 \pm 0.07$ & $1.12 \pm 0.06$ & 0.1339 \\
\hline $22: 4 n-6$ & $0.61 \pm 0.05$ & $0.64 \pm 0.05$ & 0.6137 \\
\hline 22:5n-3 (DPA) & $1.08 \pm 0.07$ & $1.16 \pm 0.07$ & 0.3288 \\
\hline 22:6n-3 (DHA) & $0.018 \pm 0.008$ & $0.012 \pm 0.006$ & 0.5109 \\
\hline Total n-3 FA & $10.14 \pm 0.46$ & $11.08 \pm 0.44$ & 0.0316 \\
\hline Total n-6 FA & $120.25 \pm 4.69$ & $122.06 \pm 4.47$ & 0.7145 \\
\hline n- $6 / n-3$ ratio & $12.19 \pm 0.31$ & $10.66 \pm 0.28$ & 0.0002 \\
\hline Total FA & $231.82 \pm 8.39$ & $234.12 \pm 7.99$ & 0.8037 \\
\hline
\end{tabular}

${ }^{1} \mathrm{DMA}=$ dimethyl acetal; ALA = alpha-linolenic acid; EPA = eicosapentaenoic acid; DPA = docosapentaenoic acid; $\mathrm{DHA}=$ docosahexaenoic acid. 
A

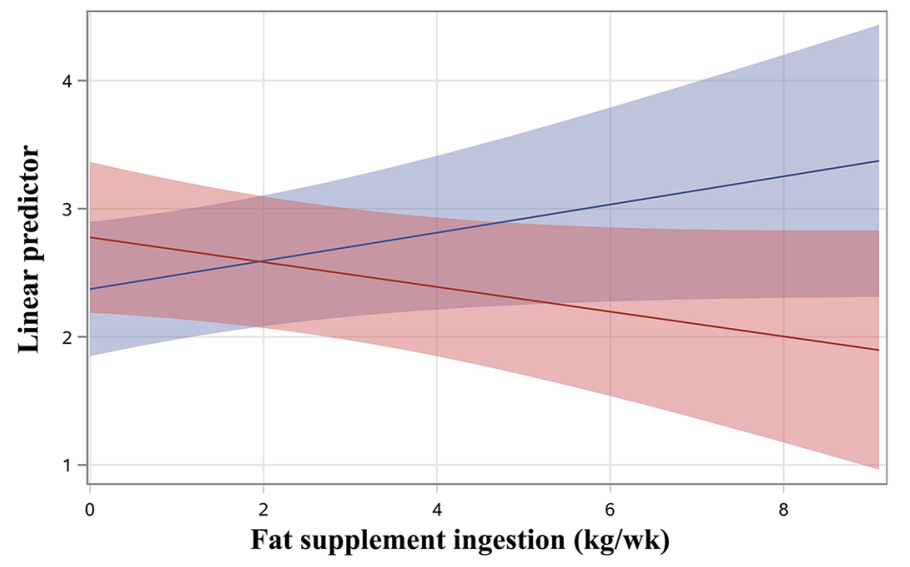

B

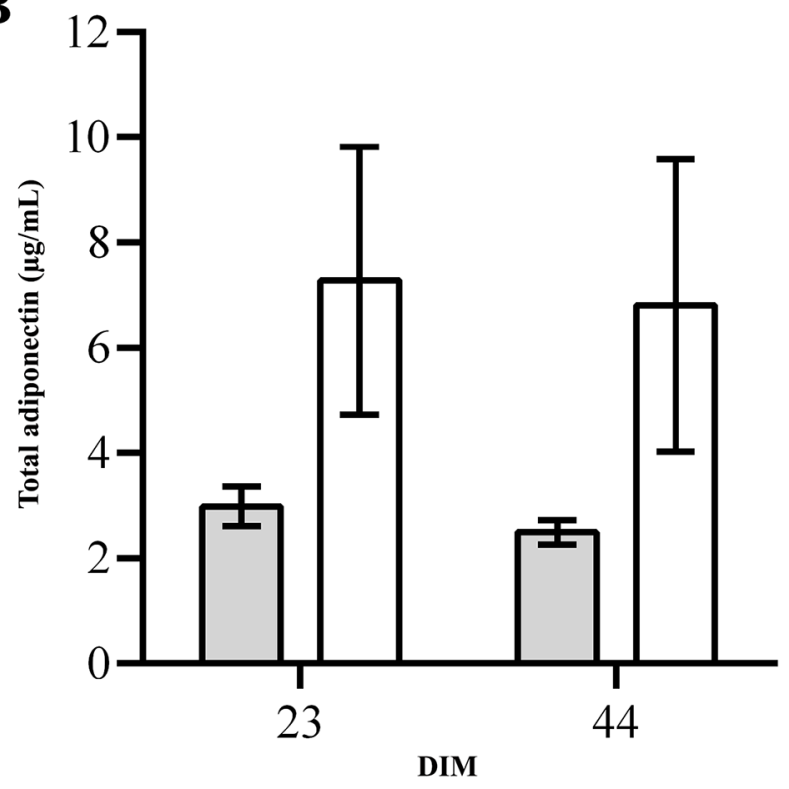

Figure 3. (A) Plot of regression lines with respective 95\% confidence limits of varying rates of weekly fat supplement ingestion effect on plasma total adiponectin concentrations in postpartum dairy cows ingesting control (blue) or n-3 PUFA (red) fat supplements. (B) Mean $( \pm \mathrm{SE})$ plasma concentrations of total adiponectin at 23 and 44 DIM of healthy cows (gray bars) and cows with cytological endometritis (white bars).

\section{Fat Supplement Intake}

We found a large individual variation in intake of both fat supplements, but n-3 PUFA had higher total ingestion than the control fat supplement. In fat-supplemented cows, DMI is affected by forage-to-concentrate ratio, supplement inclusion rate, palatability, chain length, and saturation of FA (Bionaz et al., 2020). Because the forage-to-concentrate ratio and supplement inclusion rate were kept constant, the differences in supplement intake observed between groups were probably due to palatability or to FA chain length and saturation. The irregular intake pattern of both supplements resulted in the planned daily and total dosage not being attained uniformly. Although this jeopardized the magnitude of the metabolic and reproductive effects in several cows, it allowed evaluation of the interaction between type of supplement and the amount ingested.

\section{Effects on Plasma FA Composition}

Total plasma FA concentrations increased as lactation progressed, an expected consequence of higher DMI, resulting in a higher outflow of FA from the rumen, as observed by others (Penner and Oba, 2009; Elis et al., 2016). Corroborating this, primiparous cows with lower DMI capacity (Neave et al., 2017) also had lower plasma total FA concentrations than multiparous cows. As projected, the plasma FA profile was affected by fat supplement intake. Dietary ALA from the n-3 PUFA supplement was successfully transferred into plasma following a linear relation with intake, which agrees with studies using other n-3 PUFA sources (Gonthier et al., 2005; Zachut et al., 2010; Moallem et al., 2013). As a consequence of increased plasma ALA and total $\mathrm{n}-3 \mathrm{FA}$ concentrations, the $\mathrm{n}-6 / \mathrm{n}-3$ ratio was lower in n-3 PUFA than in the control group. Both supplements increased plasma total n- 6 and LA concentrations. This was unexpected because, unlike the n-3 PUFA supplement, the control supplement had no PUFA content. Because dairy cows do not synthesize LA, the increase in plasma LA concentrations in the control group resulted from an increased TMR intake. This contrasts with the common observation that feeding fat to dairy cows decreases DMI (Moallem, 2018). Nevertheless, palmitic acid supplements have been reported to increase DMI (Mosley et al., 2007; de Souza and Lock, 2019). In fact, palmitic acid accounted for almost half of the FA present in the control fat supplement. Thus, control cows that ingested more fat supplement probably also ingested more TMR, which was likely the cause for their elevated total n-6 FA and LA in plasma. In addition, both fat supplements equally increased EPA and DPA plasma concentrations, which was unexpected as only the n-3 PUFA fat supplement increased ALA plasma concentrations, and both EPA and DPA result from the elongation of ALA (Saini and Keum, 2018). This increase in EPA and DPA plasma concentrations in cows of the control group might also be attributed to an increased TMR intake, which contained ALA. In mammals, elongation of ALA and LA to the respective n-3 and n-6 long-chain PUFA families share the same enzymatic pathways, and many tissues convert dietary ALA to EPA and DHA by desaturation and elongation 
Table 5. Reproductive outcome models with statistical significance

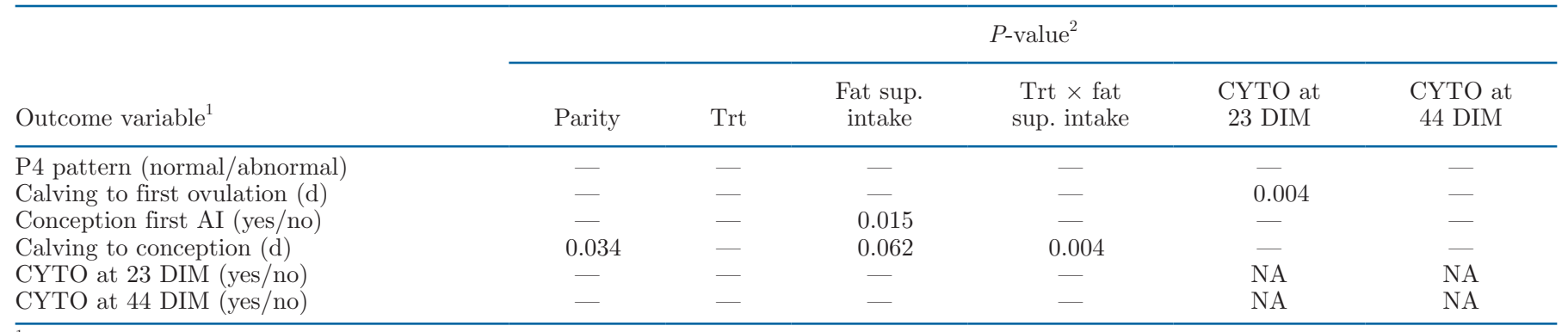

${ }^{1} \mathrm{P} 4=$ progesterone; $\mathrm{CYTO}=$ cytological endometritis.

${ }^{2}$ Trt $=$ treatment group (n-3 PUFA or control). Fat sup. intake = effect of intake of fat supplement; 1 unit = $1 \mathrm{~kg}$. Variables not included in the final models are represented by dashes $(-)$. NA $=$ not applicable.

combined with peroxisomal chain shortening (Cook and McMaster, 2002). One explanation could be that, due to a limited capacity of dairy cows converting ALA to an n-3 family long PUFA, excess ALA would remain in circulation. Alternatively, because the distribution of dietary n-3 PUFA is organ-specific (Wolf et al., 2019), blood plasma might not be the best tissue to detect putative increased EPA and DHA availability. In mammals, the pathway of ALA elongation, which has DHA as the final product, is considered highly inefficient, and ALA supplementation frequently fails to affect plasma DHA concentrations (Brenna et al., 2009). Therefore, the absence of the effect of fat supplementation on DHA concentrations was somewhat expected.

\section{Effects on Metabolic Parameters}

Fat supplementation increased milk yield but did not affect BCS. Additional energy intake can be partitioned either toward body adipose depots or toward milk production. Energy channeling toward adipose tissue occurs when there is a lack of glucose or amino acids to support increased milk synthesis (Weiss and PinosRodríguez, 2009) or when the metabolic limits (growth hormone and insulin) for milk production are reached (Bines and Hart, 1982). Weiss and Pinos-Rodríguez (2009) suggested that in a $40 \%$ forage diet, as in this study $(42 \%)$, the supplemental fat-induced increase in energy intake was largely partitioned to milk synthesis. This is in accord with results from this study, where fat supplementation did not affect glucose and BHB blood concentrations, supporting the concept that, when energy is a limiting factor, additional energy intake from fat supplementation is directed toward additional milk synthesis (Zachut et al., 2010; Haubold et al., 2020). The saturated or unsaturated nature of FA from the supplements had no effect on BCS, blood glucose, BHB, and plasma NEFA concentrations, which is in accordance with other studies (Petit et al., 2007; Zachut et al., 2010; Hutchinson et al., 2012; Dirandeh et al., 2013).

Total adiponectin plasma concentrations decreased in association with n-3 PUFA fat supplementation in a dose-dependent manner. Supplementing ALA and CLA to mid-lactation dairy cows also decreased adiponectin plasma concentrations (Haubold et al., 2020), and n-3 PUFA-supplemented cows displayed overexpression of the adiponectin gene in adipose tissue compared with n-6 PUFA-supplemented cows (Elis et al., 2016). Taken together, these data indicate that n-3 PUFA affects the adiponectin pathway, namely through adipose tissue, opening opportunities to modulate adipokine expression through feeding. However, because adiponectin promotes insulin sensitivity (Haubold et al., 2020), by reducing adiponectin plasma concentrations, n-3 PUFA supplementation may have the undesirable effect of extending a state of insulin resistance and lipid mobilization (Singh et al., 2014). Plasma total adiponectin concentrations were unaffected by BCS, which, together with data from other studies (Krumm et al., 2017; Mann et al., 2018), indicates that plasma adiponectin concentrations are remarkably irresponsive to BCS in postpartum dairy cows. In contrast, De Koster et al. (2017) found that adiponectin serum concentrations were negatively associated with BCS during the dry period. Altogether, this information favors the concept that, in postpartum dairy cows, the relation between body fat reserves and adiponectin might be uncoupled, maintaining insulin resistance and adipose tissue mobilization (Singh et al., 2014). The endometrial inflammatory status at 44 DIM affected plasma total adiponectin concentrations, with CYTO cows displaying increased concentrations. This is consistent with a previous study (Pereira et al., 2020), evidencing that postpartum increased adiponectin expression is a biomarker of persistent uterine inflammation. 


\section{Effects on FPCM Yield}

Feeding n-3 FA gave conflicting results regarding milk yield effects, some studies reporting increased yields (Moallem, 2009; Zachut et al., 2010), whereas others found no effect (Ferlay et al., 2013; Neveu et al., 2013). Reviewing the subject, Moallem (2018) suggested that contradictory results might occur from different levels of fat intake and varying degrees of rumen protection. Also, Ariza et al. (2019) suggested that, contrary to high-fat diets, supplementing moderate quantities of PUFA (extruded linseed) might increase the diet's energy density without lowering DMI or reducing fiber digestibility. Supplementation with saturated FA from palm oil also gave contrasting results, again some authors reporting increased milk yield (Mosley et al., 2007; Piantoni et al., 2013), whereas others found no effect (de Souza et al., 2016), which may reflect the basal diet composition or fat supplement characteristics (de Souza et al., 2016). These reports highlight the dose-dependent effect of fat supplementation in dairy cows' milk yield. At a lower dose, fat supplementation increases energy density and consequently milk yield, but above a certain level of supplementation, fat depresses feed intake and milk yield (Palmquist and Jenkins, 2017). In this study, both fat supplements increased FPCM yield and had no adverse effect on milk fat. A reduction in milk fat percentage can be observed following n-3 FA supplementation if the rumen biohydrogenation pathways shift to the production of 18:1 trans-10, 18:2 trans-10,cis-12, and other related intermediates known to depress milk fat (Moallem, 2018).

\section{Effects on Reproductive Parameters}

Despite decreasing the $\mathrm{n}-6 / \mathrm{n}-3$ ratio and increasing n-3 PUFA plasma concentrations, n-3 PUFA supplementation did not affect endometrial inflammation status at 23 and 44 DIM. Following PUFA supplementation, tissue concentrations take longer to increase than plasma concentrations (Cook and McMaster, 2002), making the time required to incorporate dietary n-3 FA into target tissues an important point when developing supplementation approaches (Moallem, 2018). Persistent CYTO can result from an unbalanced production of proinflammatory and anti-inflammatory cytokines during the first WPP (Arias et al., 2018), when reduced activation of proinflammatory cytokines impair the clearance of endometrial bacteria, which, coupled with persistent proinflammatory stimuli during later stages, maintain a hostile environment for the embryo (Wagener et al., 2017; Sheldon et al., 2019; Pascottini and LeBlanc, 2020). Because PUFA supplementation started at 11 DIM, one may hypothesize that it was not effective in modulating cytokine production. This could potentially be achieved by beginning fat supplementation either in the prepartum or at calving, allowing for essential PUFA to accumulate in the endometrium. Additionally, a higher dietary inclusion of PUFA, namely ALA, could prove beneficial, as daily values here registered $(102 \mathrm{~g} / \mathrm{d})$ are lower than those reported by others (162 g/d, as per Moallem, 2009; $402 \mathrm{~g} / \mathrm{d}$, as per Zachut et al., 2010; $131 \mathrm{~g} / \mathrm{d}$, as per Moallem et al., 2013). However, the interval from calving to first ovulation was affected by CYTO at 23 DIM. Uterine bacterial infection impairs early postpartum follicular development, as LPS and tumor necrosis factor- $\alpha$ suppress follicular growth and estradiol production, making affected cows less likely to ovulate the first dominant follicle (Sheldon et al., 2002; Gilbert, 2011).

Fat supplementation did not affect the onset of postpartum ovarian luteal activity, nor postpartum progesterone profiles. Dietary ratio of n-6 to n-3 PUFA can modulate prostaglandin synthesis and metabolism (Greco et al., 2018), and prostaglandins play a relevant role in uterine involution and onset of postpartum estrous cycles. Again, starting supplementation at 11 DIM might have jeopardized a beneficial effect on endometrial prostaglandin synthesis.

First-service conception rate increased in association with higher intake of both fat supplements, which agrees with data reviewed by Rodney et al. (2015). This improvement in conception rate to first AI following PUFA supplementation was related to increased LA concentrations, which would inhibit prostaglandin synthesis in the presence of trophoblast interferon, thus preventing early embryonic mortality (McNamara et al., 2003). As both n-3 PUFA and control fat supplements increased plasma LA concentrations, this could explain the observed increase in the first AI conception rate. However, cows that conceived to first AI had higher plasma concentrations of ALA, suggesting that n-3 PUFA supplementation may have exerted an additional positive effect. Interestingly, the influence on the first AI conception rate was reflected in a shorter CCI in n-3 PUFA cows but not in control-group cows. This effect in n-3 PUFA cows was proportional to ingested supplement. Although n-3 PUFA are believed to weaken the uterine inflammatory status, leading to higher chances of embryo survival (Leroy et al., 2014), the effects of n-6 and n-3 PUFA supplementation on progesterone and prostaglandin metabolism are inconsistent (Otto et al., 2014).

\section{CONCLUSIONS}

Supplement feeding with PUFA or saturated FA of postpartum high-yielding dairy cows increased FPCM 
yield. Although PUFA and saturated FA supplements increased plasma LA, only the n-3 PUFA supplement increased plasma ALA concentrations and regulated adiponectin expression. Fat supplementation increased first AI conception rate, and n-3 PUFA supplement shortened the CCI in a mechanism independent of early return to postpartum ovarian activity, postpartum progesterone patterns, or persistent endometrial inflammation. These findings highlight the potential of n-3 PUFA to improve high-yielding dairy cows' fertility by favoring early conception in the postpartum period. However, to prevent postpartum persistent endometrial inflammation, alternative n-3 PUFA supplementation regimens must be developed, namely with rumenprotected EPA and DHA sources, due to the inefficient elongation of ALA. Moreover, the mechanisms behind the improvement of fertility following n-3 PUFA supplementation warrant further studies.

\section{ACKNOWLEDGMENTS}

The authors are grateful to Jerónimo Pinto and Eurocereal (Malveira, Portugal) for the kind donation of the encapsulated linseed (n-3 PUFA) supplement. We also thank Barão \& Barão Lda for providing the facilities for this study and for their assistance with animal care. Gonçalo Pereira is a $\mathrm{PhD}$ student supported by a grant from Fundação para a Ciência e Tecnologia (FCT; Lisboa, Portugal; SFRH/BD/130923/2017). Elisabete Silva (DL 57/2016/CP1438/CT0001) and Susana Alves (DL 57/2016/CP1438/CT0008) are also funded by FCT. This work was supported by FCT, grant UIDB/00276/2020 and project NAT-OMEGA3 (PDR2020-1.0.1-FEADER-031461). The authors have not stated any conflicts of interest.

\section{REFERENCES}

Abdelli, A., D. Raboisson, R. Kaidi, B. Ibrahim, A. Kalem, and M. Iguer-Ouada. 2017. Elevated non-esterified fatty acid and $\beta$-hydroxybutyrate in transition dairy cows and their association with reproductive performance and disorders: A metaanalysis. Theriogenology 93:99-104. https://doi.org/10.1016/j .theriogenology.2017.01.030.

Ackman, R. G. 2002. The gas chromatograph in practical analyses of common and uncommon fatty acids for the 21st century. Anal. Chim. Acta 465:175-192. https://doi.org/10.1016/S0003 -2670(02)00098-3.

Alves, S. P., A. Francisco, M. Costa, J. Santos-Silva, and R. J. B. Bessa. 2017. Biohydrogenation patterns in digestive contents and plasma of lambs fed increasing levels of a tanniferous bush (Cistus ladanifer L.) and vegetable oils. Anim. Feed Sci. Technol. 225:157172. https://doi.org/10.1016/j.anifeedsci.2017.01.018.

Arias, L. A. Q., M. V. Fernández, J. J. B. González, M. B. López, P. J. G. Herradón, and A. I. P. Martínez. 2018. Subclinical endometritis in dairy cattle. Pages 79-97 in New Insights Into Theriogenology. R. Payan-Carreira, ed. Intech. https://doi.org/10.5772/intechopen .80229 .
Ariza, J. M., T. Meignan, A. Madouasse, F. Beaudeau, and N. Bareille. 2019. Effects on milk quantity and composition associated with extruded linseed supplementation to dairy cow diets. Sci. Rep. 9:17563. https://doi.org/10.1038/s41598-019-54193-z.

Bines, J. A., and I. C. Hart. 1982. Metabolic limits to milk production, especially roles of growth hormone and insulin. J. Dairy Sci. 65:1375-1389. https://doi.org/10.3168/jds.S0022-0302(82)82358 -8 .

Bionaz, M., E. Vargas-Bello-Pérez, and S. Busato. 2020. Advances in fatty acids nutrition in dairy cows: from gut to cells and effects on performance. J. Anim. Sci. Biotechnol. 11:110. https://doi.org/10 $.1186 / \mathrm{s} 40104-020-00512-8$.

Bradford, B. J., K. Yuan, J. K. Farney, L. K. Mamedova, and A. J. Carpenter. 2015. Invited review: Inflammation during the transition to lactation: New adventures with an old flame. J. Dairy Sci. 98:6631-6650. https://doi.org/10.3168/jds.2015-9683.

Brenna, J. T., N. J. Salem Jr., A. J. Sinclair, and S. C. Cunnane. 2009. $\alpha$-Linolenic acid supplementation and conversion to n-3 long-chain polyunsaturated fatty acids in humans. Prostaglandins Leukot. Essent. Fatty Acids 80:85-91. https://doi.org/10.1016/j.plefa.2009 .01 .004 .

Caixeta, L. S., P. A. Ospina, M. B. Capel, and D. V. Nydam. 2017. Association between subclinical hypocalcemia in the first 3 days of lactation and reproductive performance of dairy cows. Theriogenology 94:1-7. https://doi.org/10.1016/j.theriogenology.2017.01 .039 .

Chamberlain, M. B., and E. J. DePeters. 2017. Impacts of feeding lipids supplements high in palmitic acid or stearic acid on performance of lactating dairy cows. J. Appl. Anim. Res. 45:126-135. https://doi.org/10.1080/09712119.2015.1124327.

Chamberlin, W. G., J. R. Middleton, J. N. Spain, G. C. Johnson, M. R. Ellersieck, and P. Pithua. 2013. Subclinical hypocalcemia, plasma biochemical parameters, lipid metabolism, postpartum disease, and fertility in postparturient dairy cows. J. Dairy Sci. 96:7001-7013. https://doi.org/10.3168/jds.2013-6901.

Colazo, M. G., D. J. Ambrose, J. P. Kastelic, and J. A. Small. 2008. Comparison of 2 enzyme immunoassays and a radioimmunoassay for measurement of progesterone concentrations in bovine plasma, skim milk, and whole milk. Can. J. Vet. Res. 72:32-36.

Cook, H. W., and C. R. McMaster. 2002. Fatty acid desaturation and chain elongation in eukaryotes. New Compr. Biochem. 36:181-204. https://doi.org/10.1016/S0167-7306(02)36009-5.

De Koster, J., C. Urh, M. Hostens, W. Van den Broeck, H. Sauerwein, and G. Opsomer. 2017. Relationship between serum adiponectin concentration, body condition score, and peripheral tissue insulin response of dairy cows during the dry period. Domest. Anim. Endocrinol. 59:100-104. https://doi.org/10.1016/j.domaniend.2016 .12 .004 .

de Souza, J., and A. L. Lock. 2019. Effects of timing of palmitic acid supplementation on production responses of early-lactation dairy cows. J. Dairy Sci. 102:260-273. https://doi.org/10.3168/jds.2018 -14976 .

de Souza, J., C. L. Preseault, and A. L. Lock. 2016. Short communication: Lactational responses to palmitic acid supplementation when replacing soyhulls or dry ground corn. J. Dairy Sci. 99:1945-1950. https://doi.org/10.3168/jds.2015-10367.

Dirandeh, E., A. Towhidi, S. Zeinoaldini, M. Ganjkhanlou, Z. Ansari Pirsaraei, and A. Fouladi-Nashta. 2013. Effects of different polyunsaturated fatty acid supplementations during the postpartum periods of early lactating dairy cows on milk yield, metabolic responses, and reproductive performances. J. Anim. Sci. 91:713-721. https://doi.org/10.2527/jas.2012-5359.

Elis, S., A. Desmarchais, S. Freret, V. Maillard, V. Labas, J. Cognié, E. Briant, C. Hivelin, J. Dupont, and S. Uzbekova. 2016. Effect of a long-chain n-3 polyunsaturated fatty acid-enriched diet on adipose tissue lipid profiles and gene expression in Holstein dairy cows. J. Dairy Sci. 99:10109-10127. https://doi.org/10.3168/jds .2016-11052.

Ferguson, J. D., D. T. Galligan, and N. Thomsen. 1994. Principal descriptors of body condition score in Holstein cows. J. Dairy Sci. 
77:2695-2703. https://doi.org/10.3168/jds.S0022-0302(94)77212 -X.

Ferlay, A., M. Doreau, C. Martin, and Y. Chilliard. 2013. Effects of incremental amounts of extruded linseed on the milk fatty acid composition of dairy cows receiving hay or corn silage. J. Dairy Sci. 96:6577-6595. https://doi.org/10.3168/jds.2013-6562.

Gilbert, R. O. 2011. The effects of endometritis on the establishment of pregnancy in cattle. Reprod. Fertil. Dev. 24:252-257. https:// doi.org/10.1071/RD11915.

Gilbert, R. O., S. T. Shin, C. L. Guard, H. N. Erb, and M. Frajblat. 2005. Prevalence of endometritis and its effects on reproductive performance of dairy cows. Theriogenology 64:1879-1888. https:// doi.org/10.1016/j.theriogenology.2005.04.022.

Gonthier, C., A. F. Mustafa, D. R. Ouellet, P. Y. Chouinard, R. Berthiaume, and H. V. Petit. 2005. Feeding micronized and extruded flaxseed to dairy cows: Effects on blood parameters and milk fatty acid composition. J. Dairy Sci. 88:748-756. https://doi.org/10 .3168/jds.S0022-0302(05)72738-7.

Greco, L. F., J. T. Neves Neto, A. Pedrico, R. A. Ferrazza, F. S. Lima, R. S. Bisinotto, N. Martinez, M. Garcia, E. S. Ribeiro, G. C. Gomes, J. H. Shin, M. A. Ballou, W. W. Thatcher, C. R. Staples, and J. E. P. Santos. 2015. Effects of altering the ratio of dietary n- 6 to n-3 fatty acids on performance and inflammatory responses to a lipopolysaccharide challenge in lactating Holstein cows. J. Dairy Sci. 98:602-617. https://doi.org/10.3168/jds.2014-8805.

Greco, L. F., J. T. Neves Neto, A. Pedrico, F. S. Lima, R. S. Bisinotto, N. Martinez, E. S. Ribeiro, W. W. Thatcher, C. R. Staples, and J. E. P. Santos. 2018. Effects of altering the ratio of dietary n-6 to n-3 fatty acids on spontaneous luteolysis in lactating dairy cows. J. Dairy Sci. 101:10536-10556. https://doi.org/10.3168/jds.2018 -15065 .

Haubold, S., C. Kröger-Koch, A. Tuchscherer, E. Kanitz, J. M. Weitzel, A. Hoeflich, A. Starke, A. Tröscher, H. Sauerwein, and H. M. Hammon. 2020. Effects of a combined essential fatty acid and conjugated linoleic acid abomasal infusion on metabolic and endocrine traits, including the somatotropic axis, in dairy cows. J. Dairy Sci. 103:12069-12082. https://doi.org/10.3168/jds.2020-18569.

Heinze, G., and D. Dunkler. 2017. Five myths about variable selection. Transpl. Int. 30:6-10. https://doi.org/10.1111/tri.12895.

Herrera-Camacho, J., A. Soberano-Martinez, K. E. Orozco Duran, C. Aguilar-Perez, and J. C. Ku-Vera. 2011. Effect of fatty acids on reproductive performance of ruminants. Pages 217-242 in Artificial Insemination in Farm Animals. M. Manafi, ed. Intech. https://doi .org/10.5772/16938.

Hutchinson, I. A., A. A. Hennessy, S. M. Waters, R. J. Dewhurst, A. C. O. Evans, P. Lonergan, and S. T. Butler. 2012. Effect of supplementation with different fat sources on the mechanisms involved in reproductive performance in lactating dairy cattle. Theriogenology 78:12-27. https://doi.org/10.1016/j.theriogenology.2011.12.031.

Kasimanickam, R., T. F. Duffield, R. A. Foster, C. J. Gartley, K. E. Leslie, J. S. Walton, and W. H. Johnson. 2004. Endometrial cytology and ultrasonography for the detection of subclinical endometritis in postpartum dairy cows. Theriogenology 62:9-23. https:// doi.org/10.1016/j.theriogenology.2003.03.001.

Kok, A., A. T. M. van Knegsel, C. E. van Middelaar, B. Engel, H. Hogeveen, B. Kemp, and I. J. M. de Boer. 2017. Effect of dry period length on milk yield over multiple lactations. J. Dairy Sci. 100:739-749. https://doi.org/10.3168/jds.2016-10963.

Krumm, C. S., S. L. Giesy, L. S. Caixeta, W. R. Butler, H. Sauerwein, J. W. Kim, and Y. R. Boisclair. 2017. Effect of hormonal and energy-related factors on plasma adiponectin in transition dairy cows. J. Dairy Sci. 100:9418-9427. https://doi.org/10.3168/jds .2017-13274.

Lamming, G. E., and A. O. Darwash. 1998. The use of milk progesterone profiles to characterize components of subfertility in milked dairy cows. Anim. Reprod. Sci. 52:175-190. https://doi.org/10 $.1016 /$ S0378-4320(98)00099-2.

Lean, I. J., M. C. Lucy, J. P. McNamara, B. J. Bradford, E. Block, J. M. Thomson, J. M. Morton, P. Celi, A. R. Rabiee, J. E. Santos, W. W. Thatcher, and S. J. LeBlanc. 2016. Invited review: Recommendations for reporting intervention studies on reproductive performance in dairy cattle: Improving design, analysis, and interpretation of research on reproduction. J. Dairy Sci. 99:1-17. https: //doi.org/10.3168/jds.2015-9445.

LeBlanc, S. J. 2012. Interactions of metabolism, inflammation, and reproductive tract health in the postpartum period in dairy cattle. Reprod. Domest. Anim. 47(Suppl. 5):18-30. https://doi.org/10 .1111/j.1439-0531.2012.02109.x.

Leroy, J. L. M. R., R. G. Sturmey, V. Van Hoeck, J. De Bie, P. J. McKeegan, and P. E. J. Bols. 2014. Dietary fat supplementation and the consequences for oocyte and embryo quality: Hype or significant benefit for dairy cow reproduction? Reprod. Domest. Anim. 49:353-361. https://doi.org/10.1111/rda.12308.

Mann, S., C. Urh, H. Sauerwein, J. J. Wakshlag, F. A. Leal Yepes, T. R. Overton, and D. V. Nydam. 2018. Short communication: The association of adiponectin and leptin concentrations with prepartum dietary energy supply, parity, body condition, and postpartum hyperketonemia in transition dairy cows. J. Dairy Sci. 101:806-811. https://doi.org/10.3168/jds.2017-13752.

Manriquez, D., L. Chen, P. Melendez, and P. Pinedo. 2019. The effect of an organic rumen-protected fat supplement on performance, metabolic status, and health of dairy cows. BMC Vet. Res. 15:450. https://doi.org/10.1186/s12917-019-2199-8.

Martin, J. L., K. A. Vonnahme, D. C. Adams, G. P. Lardy, and R. N. Funston. 2007. Effects of dam nutrition on growth and reproductive performance of heifer calves. J. Anim. Sci. 85:841-847. https: //doi.org/10.2527/jas.2006-337.

Martinez, N., C. A. Risco, F. S. Lima, R. S. Bisinotto, L. F. Greco, E. S. Ribeiro, F. Maunsell, K. Galvão, and J. E. Santos. 2012. Evaluation of peripartal calcium status, energetic profile, and neutrophil function in dairy cows at low or high risk of developing uterine disease. J. Dairy Sci. 95:7158-7172. https://doi.org/10.3168/jds $.2012-5812$.

McNamara, S., T. Butler, D. P. Ryan, J. F. Mee, P. Dillon, F. P. O'Mara, S. T. Butler, D. Anglesey, M. Rath, and J. J. Murphy. 2003. Effect of offering rumen-protected fat supplements on fertility and performance in spring-calving Holstein-Friesian cows. Anim. Reprod. Sci. 79:45-56. https://doi.org/10.1016/S0378 $-4320(03) 00111-8$

Mellouk, N., C. Ramé, M. Diot, E. Briant, J. L. Touzé, D. Guillaume, P. Froment, and J. Dupont. 2019. Possible involvement of the RARRES2/CMKLR1-system in metabolic and reproductive parameters in Holstein dairy cows. Reprod. Biol. Endocrinol. 17:25. https://doi.org/10.1186/s12958-019-0467-x.

Mellouk, N., C. Ramé, J. L. Touzé, E. Briant, L. Ma, D. Guillaume, D. Lomet, A. Caraty, T. Ntallaris, P. Humblot, and J. Dupont. 2017. Involvement of plasma adipokines in metabolic and reproductive parameters in Holstein dairy cows fed with diets with differing energy levels. J. Dairy Sci. 100:8518-8533. https://doi.org/10.3168/ jds.2017-12657.

Moallem, U. 2009. The effects of extruded flaxseed supplementation to high-yielding dairy cows on milk production and milk fatty acid composition. Anim. Feed Sci. Technol. 152:232-242. https://doi .org/10.1016/j.anifeedsci.2009.04.018.

Moallem, U. 2018. Invited review: Roles of dietary n-3 fatty acids in performance, milk fat composition, and reproductive and immune systems in dairy cattle. J. Dairy Sci. 101:8641-8661. https://doi .org/10.3168/jds.2018-14772.

Moallem, U., H. Lehrer, L. Livshits, and M. Zachut. 2020. The effects of omega- $3 \alpha$-linolenic acid from flaxseed oil supplemented to highyielding dairy cows on production, health, and fertility. Livest. Sci. 242:104302. https://doi.org/10.1016/j.livsci.2020.104302.

Moallem, U., A. Shafran, M. Zachut, I. Dekel, Y. Portnick, and A. Arieli. 2013. Dietary $\alpha$-linolenic acid from flaxseed oil improved folliculogenesis and IVF performance in dairy cows, similar to eicosapentaenoic and docosahexaenoic acids from fish oil. Reproduction 146:603-614. https://doi.org/10.1530/REP-13-0244.

Mosley, S. A., E. E. Mosley, B. Hatch, J. I. Szasz, A. Corato, N. Zacharias, D. Howes, and M. A. McGuire. 2007. Effect of varying levels of fatty acids from palm oil on feed intake and milk production in Holstein cows. J. Dairy Sci. 90:987-993. https://doi.org/10.3168/ jds.S0022-0302(07)71583-7. 
Neave, H. W., J. Lomb, M. A. G. von Keyserlingk, A. Behnam-Shabahang, and D. M. Weary. 2017. Parity differences in the behavior of transition dairy cows. J. Dairy Sci. 100:548-561. https://doi.org/ 10.3168/jds.2016-10987.

Neveu, C., B. Baurhoo, and A. Mustafa. 2013. Effect of feeding extruded flaxseed with different forage:concentrate ratios on the performance of dairy cows. J. Dairy Sci. 96:3886-3894. https://doi .org/10.3168/jds.2012-6189.

Opgenorth, J., L. M. Sordillo, and M. J. VandeHaar. 2020. Colostrum supplementation with n-3 fatty acids and $\alpha$-tocopherol alters plasma polyunsaturated fatty acid profile and decreases an indicator of oxidative stress in newborn calves. J. Dairy Sci. 103:3545-3553. https://doi.org/10.3168/jds.2019-17380.

Otto, J. R., M. J. Freeman, B. S. Malau-Aduli, P. D. Nichols, P. A. Lane, and A. E. O. Malau-Aduli. 2014. Reproduction and fertility parameters of dairy cows supplemented with omega-3 fatty acidrich canola oil. Annu. Res. Rev. Biol. 4:1611-1636. https://doi .org/10.9734/ARRB/2014/7689.

Palmquist, D. L., and T. C. Jenkins. 2017. A 100-Year Review: Fat feeding of dairy cows. J. Dairy Sci. 100:10061-10077. https://doi .org/10.3168/jds.2017-12924.

Pascottini, O. B., and S. J. LeBlanc. 2020. Modulation of immune function in the bovine uterus peripartum. Theriogenology 150:193-200. https://doi.org/10.1016/j.theriogenology.2020.01.042.

Penner, G. B., and M. Oba. 2009. Increasing dietary sugar concentration may improve dry matter intake, ruminal fermentation, and productivity of dairy cows in the postpartum phase of the transition period. J. Dairy Sci. 92:3341-3353. https://doi.org/10.3168/ jds.2008-1977.

Pereira, G. 2021. Supplemental Figure S1. https://doi.org/10.17632/ j2bfm4tf9x.1.

Pereira, G., R. Bexiga, J. Chagas e Silva, E. Silva, C. Ramé, J. Dupont, Y. Guo, P. Humblot, and L. Lopes-da-Costa. 2020. Adipokines as biomarkers of postpartum subclinical endometritis in dairy cows. Reproduction 160:417-430. https://doi.org/10.1530/ REP-20-0183.

Petit, H. V., M. F. Palin, and L. Doepel. 2007. Hepatic lipid metabolism in transition dairy cows fed flaxseed. J. Dairy Sci. 90:4780 4792. https://doi.org/10.3168/jds.2007-0066.

Piantoni, P., A. L. Lock, and M. S. Allen. 2013. Palmitic acid increased yields of milk and milk fat and nutrient digestibility across production level of lactating cows. J. Dairy Sci. 96:7143-7154. https://doi .org/10.3168/jds.2013-6680.

Raboisson, D., M. Mounié, and E. Maigné. 2014. Diseases, reproductive performance, and changes in milk production associated with subclinical ketosis in dairy cows: A meta-analysis and review. J. Dairy Sci. 97:7547-7563. https://doi.org/10.3168/jds.2014-8237.

Rodney, R. M., P. Celi, W. Scott, K. Breinhild, and I. J. Lean. 2015. Effects of dietary fat on fertility of dairy cattle: A meta-analysis and meta-regression. J. Dairy Sci. 98:5601-5620. https://doi.org/ 10.3168/jds.2015-9528.

Saini, R. K., and Y. S. Keum. 2018. Omega-3 and omega-6 polyunsaturated fatty acids: Dietary sources, metabolism, and significanceA review. Life Sci. 203:255-267. https://doi.org/10.1016/j.lfs.2018 .04 .049 .

Sheldon, I. M., J. G. Cronin, and J. J. Bromfield. 2019. Tolerance and innate immunity shape the development of postpartum uterine disease and the impact of endometritis in dairy cattle. Annu. Rev. Anim. Biosci. 7:361-384. https://doi.org/10.1146/annurev-animal $-020518-115227$.
Sheldon, I. M., D. E. Noakes, A. N. Rycroft, D. U. Pfeiffer, and H. Dobson. 2002. Influence of uterine bacterial contamination after parturition on ovarian dominant follicle selection and follicle growth and function in cattle. Reproduction 123:837-845. https:/ /doi.org/10.1530/rep.0.1230837.

Singh, S. P., S. Häussler, J. J. Gross, F. J. Schwarz, R. M. Bruckmaier, and H. Sauerwein. 2014. Short communication: Circulating and milk adiponectin change differently during energy deficiency at different stages of lactation in dairy cows. J. Dairy Sci. 97:15351542. https://doi.org/10.3168/jds.2013-7598.

Uken, K. L., C. T. Schäff, L. Vogel, M. Gnott, D. Dannenberger, S. Görs, A. Tuchscherer, A. Tröscher, W. Liermann, and H. M. Hammon. 2021a. Modulation of colostrum composition and fatty acid status in neonatal calves by maternal supplementation with essential fatty acids and conjugated linoleic acid starting in late lactation. J. Dairy Sci. 104:4950-4969. https://doi.org/10.3168/ jds.2020-19627.

Uken, K. L., L. Vogel, M. Gnott, S. Görs, C. T. Schäff, A. Tuchscherer, A. Hoeflich, J. M. Weitzel, E. Kanitz, A. Tröscher, H. Sauerwein, R. Zitnan, R. M. Bruckmaier, J. J. Gross, W. Liermann, and H. M. Hammon. 2021b. Effect of maternal supplementation with essential fatty acids and conjugated linoleic acid on metabolic and endocrine development in neonatal calves. J. Dairy Sci. 104:72957314. https://doi.org/10.3168/jds.2020-20039.

Wagener, K., C. Gabler, and M. Drillich. 2017. A review of the ongoing discussion about definition, diagnosis and pathomechanism of subclinical endometritis in dairy cows. Theriogenology 94:21-30. https://doi.org/10.1016/j.theriogenology.2017.02.005.

Weiss, W. P., and J. M. Pinos-Rodríguez. 2009. Production responses of dairy cows when fed supplemental fat in low- and high-forage diets. J. Dairy Sci. 92:6144-6155. https://doi.org/10.3168/jds.2009 -2558 .

Williams, E. J., D. P. Fischer, D. U. Pfeiffer, G. C. W. England, D. E. Noakes, H. Dobson, and I. M. Sheldon. 2005. Clinical evaluation of postpartum vaginal mucus reflects uterine bacterial infection and the immune response in cattle. Theriogenology 63:102-117. https: //doi.org/10.1016/j.theriogenology.2004.03.017.

Wolf, C., N. Gredig, S. E. Ulbrich, M. Kreuzer, J. Berard, and K. Giller. 2019. Partitioning of rumen-protected n-3 and n-6 fatty acids is organ-specific in growing Angus heifers. Lipids 54:503-517. https://doi.org/10.1002/lipd.12183.

Zachut, M., A. Arieli, H. Lehrer, L. Livshitz, S. Yakoby, and U. Moallem. 2010. Effects of increased supplementation of n-3 fatty acids to transition dairy cows on performance and fatty acid profile in plasma, adipose tissue, and milk fat. J. Dairy Sci. 93:5877-5889. https://doi.org/10.3168/jds.2010-3427.

\section{ORCIDS}

Gonçalo Pereira ำ https://orcid.org/0000-0003-3533-6893 Patrícia Simões ๑ https://orcid.org/0000-0003-1598-1852 Ricardo Bexiga (ำ https://orcid.org/0000-0002-2524-9887 Elisabete Silva ๑ https://orcid.org/0000-0002-2332-7642 Tatiane Fernandes ๑ https://orcid.org/0000-0002-9825-5735 Susana P. Alves ำ https://orcid.org/0000-0002-3171-9566 Rui J. B. Bessa ๑ https://orcid.org/0000-0003-4109-3488 Luis Lopes-da-Costa ํㅜ https://orcid.org/0000-0001-5165-3034 